\title{
Smoking kills you, littering butts damages others too: analysing sustainable consumer behaviour in the era of circular economy
}

\author{
Shahid Rasool ${ }^{1,2} \cdot$ Roberto Cerchione $^{3}$ (D) Piera Centobelli ${ }^{4} \cdot$ Eugenio Oropallo $^{4}$
}

Received: 6 December 2019 / Accepted: 4 August 2021 / Published online: 2 November 2021

(c) The Author(s) 2021

\begin{abstract}
Although litter prevention has environmental, social and economic benefits, cigarette butts are the most littered item on earth. While there has been vast research into the relationship between different factors affecting consumer behaviour, further research is needed to examine the antecedents of consumer sustainable behaviour. The aim of this study is to test the impact of feared self and landfill awareness on the sustainable behaviour of consumers using a structural equation modelling approach. Primary data of consumers are used to validate the hypothesised model. The findings highlight that feared self has a positive impact on the sustainable behaviour of consumers, while feared-self congruency and landfill awareness do not affect consumer sustainable behaviour. As for the implications, the results can support academics and strategic managers in the design process of sustainable consumer awareness programs to achieve environmental, social and economic benefits in the era of circular economy.
\end{abstract}

Keywords Cigarette butt littering $\cdot$ Cigarette waste $\cdot$ Circular economy $\cdot$ Consumer behaviour - Environmental behaviour - Feared self · Landfill awareness · Littered cigarette butts · Sustainable behaviour · Structural equation modelling (SEM) - Sustainability · Tobacco industry

Roberto Cerchione

roberto.cerchione@uniparthenope.it

Shahid Rasool

shahid.ms@stmu.edu.pk; dr.rasool@monarch-university.ch

Piera Centobelli

piera.centobelli@unina.it

Eugenio Oropallo

eugenio.oropallo@unina.it

1 Shifa Tameer-E-Millat University, Jaffar Khan Jamali Road, Sector H-8/4, Islamabad, Pakistan

2 Monarch Business School, Flurstrasse 1, PO Box 30, CH-6332 Hagendorn-Zug, Switzerland

3 Department of Engineering, University of Naples Parthenope, Naples, Italy

4 Department of Industrial Engineering, University of Naples Federico II, Naples, Italy 


\section{Introduction}

Starting from 1950s, cigarette butts or filters were developed to protect smokers from diseases such as lung cancer (US Department of Health and Human Services, 1981). The social and governmental components of environmental challenges have become increasingly influential, to the point of advocating for the implementation of specific policies that affect cigarette butts littering (Rajesh \& Rajendran, 2020). Even after numerous health awareness campaigns, in 2018, the World Health Organization summed up the worldwide number of smokers to a total of 1.1 billion (WHO, 2018), and the production of cigarettes has increased to support the growing need (Zafeiridou et al., 2018). In the last years, there has been an increase in environmental social awareness (Rajesh, 2020), but smokers are wasting 5.8 trillion cigarette butts worldwide, causing serious landfill and economic issues (Leistikow et al., 2000; Novotny et al., 2009; Rahman et al., 2020). Furthermore, in the wake of an ever-growing sensitivity to environmental issues (Rajesh, 2018, 2020), the World Health Organization declared cigarette butts littering to be a landfill hazard, promoting several initiatives to find a reuse for the cigarette butts that are infesting the world's streets and landfills. For instance, cigarette butts could be used as fibre modifier in bitumen for asphalt concrete (Rahman et al., 2020), as a precursor for the preparation of mosquito pesticides and as tools for malaria vector management (Murugan et al., 2018), or as an eco-friendly row material in ceramic roofing tile (Maciel et al., 2020). If cigarette butts were collected separately, they could be recycled, and this aspect would have a positive impact on the environment. Unfortunately, it has been shown that only a tiny part is collected and that $75 \%$ of cigarette butts are often dumped on beaches, parks, footpaths, and other public spaces, posing a severe landfill threat (Al-Khatib et al., 2009; Novotny et al., 2009, 2011; Rahman et al., 2020). Due to the impossibility of separating cigarette butts from the rest of the waste collected on the ground, most countries dump them alongside other waste in landfills, while others incinerate them, emitting toxic fumes and causing severe air pollution (Knox, 2005; Krishna \& Swamy, 2016). Landfill pollution control groups have attempted to raise the concern of environmental contamination by tobacco smokers through various methods (Abdul-Wahab, 2006). People have also been motivated to quit smoking by fear messaging (Laroche et al., 2001). According to new research, using anxiety appeals in conjunction with self-affirmation theory can help people feel better (Memish et al., 2017). As a result, if a person believes there is a link between his or her current activities and a prospective poor self-perception, he or she is more inclined to change his or her current behaviour. This pessimistic self-perception is known as a feared self.

Leveraging on the self-affirmation theory, user self-concept is a multidimensional model that has been extensively researched in the field of consumer behaviour (Sirgy et al., 2000; Ekinci \& Riley, 2003; Back, 2005; Kressmann et al., 2006). Actual self, ideal self, social self, and ideal social self are four aspects that are often discussed in marketing studies (Back, 2005; Ekinci \& Riley, 2003; Kressmann et al., 2006). Earlier research has established the consistency between self-concept and product name, brand image, or personality depending on the number of self-concepts (Hosany \& Martin, 2012). However, no analysis of self-concept based on feared self and landfill perception, particularly concerning cigarette butts littering behaviour, has been conducted using the self-congruence hypothesis (Birdwell, 1968; Dolich, 1969; Hong \& Zinkhan, 1995; Landon, 1974; Malhotra, 1988; Slaughter et al., 2010). Fear of oneself may be a valid, important antecedent for raising the consciousness of cigarette butts littering activity and quitting smoking (Gilbert, 1993). 
In the social marketing literature, there are major theoretical and empirical gaps in our knowledge of cigarette butts littering behaviour (McKenzie-Mohr, 2011). There are few studies that look into the relationship between consumer self-concept (fearful self) and environmental consciousness. As a result, the aim of this research is to investigate how successful the idea of feared self is at minimising cigarette butts littering (Sobh et al., 2013; Aaker \& Lee, 2001; Pennington \& Roese, 2002).

The aim of the study is to focus on the consumer self-concept that is rooted in the consumers' feared self and raise consciousness about cigarette butts littering. As a result, the problem statement was divided into three main sub-objectives: (1) investigate the effect of customer self-consciousness and environmental concern on cigarette butts littering, (2) explore the interaction between consumers' self-consciousness and environmental understanding, also known as congruity, and (3) analyse how the congruity between scared self and environmental consciousness influences customer cigarette butts littering behaviour. While feared self and consumer landfill consciousness are antecedents of consumer cigarette butts littering behaviour, the empirical findings challenge conventional wisdom. The results show a good association between feared self and landfill awareness, which supports in establishing the feared self-landfill awareness congruency. The congruity effect on customer cigarette butts littering behaviour is also highlighted in this study. Following the introduction, the second section presents the findings of a literature review. In the third section, the methodology is explored. In the fourth and fifth sections, the results of structural equation modelling are presented and discussed. Conclusions and implications are presented in the final section.

\section{Literature review}

\subsection{Cigarette butts littering behaviour}

Although several research contributions have been conducted to better understand cigarette butts littering behaviour, the majority has given only a limited insight and usefulness in reducing cigarette butts littering (Cope et al., 1993; Novotny et al., 2009; Smith \& Novotny, 2011; Schultz et al., 2013; Lee et al., 2012; Rath et al., 2012; González-Salgado et al., 2020; Dehdari, 2020; Valiente et al., 2020; Rasool et al., 2021). Based on previous studies, Fransson and Gärling (1999) refer to personal values, landfill awareness, individual accountability, law enforcement, and education as critical factors influencing littering behaviour. Habits, disposal convenience, a lack of ashtrays, accidental tossing of the cigarette due to its tiny size, and a lack of awareness and assumption that cigarette butts are biodegradable are only a few of the causes for such behaviours (Cope et al., 1993; Lehman and Geller 2004; Novotny et al., 2009; Smith \& Novotny, 2011; Williams, 2012; Mohajerani et al., 2020; Oliva et al., 2021).

As a self-identity behaviour, a frightened self is a multidimensional notion that encompasses many different aspects of an individual's self: an expected-self, an actual-self, a hoped-for self, a feared self, and an extended self (Markus \& Nurius, 1986; Markus \& Wurf, 1987; Belk, 1988; Markus \& Ruvolo, 1989; Morgan, 1993; MacInnis \& Chun, 2007). Self-identities are an important predictor of wide ranges of behaviours, examples of selfidentities range from being a user of modern technology (Wolf \& Seebauer, 2014; King et al., 2019) to being healthy (Heinen, 2016), as well as a pro-environmental and green 
consumer (Cătălin \& Andreea, 2014; Heinen, 2016; Gatersleben et al., 2019; Derikx \& van Lierop, 2021; Rasool et al., 2021).

The phrases hoped-for and expected-self have a positive meaning, whereas feared-self has been associated with the risk of a negative outcome (Carver \& Scheier, 2001; Ogilvie, 1987; Stefan, 2012; Vergara-Lopez \& Roberts, 2012; Williams, 2012). A well-crafted fear message improves awareness of the problem and helps to convey the gravity of the situation to the target audience (Johnston \& Warkentin, 2010; Rogers, 1975; Witte, 1992; LaTour \& Pitts, 1989; Carver et al., 1999). Carver et al. (1999) discovered a close correlation between the feared self and customer behaviour in goods and service consumption. However, $\mathrm{H} 1$ is formulated from the above stance as follows:

H1 Feared self has a negative significant influence on cigarette butts littering behaviour.

\subsubsection{Landfill awareness' effect on cigarette butts littering behaviour}

Landfill awareness has a greater sense than just knowing about the environment. It also refers to people's attitudes, abilities, and values when it comes to addressing environmental issues (Baptiste, 2008; Kollmuss \& Agyeman, 2002; Kollmuss \& Agyeman, 2002; Xu et al., 2013). Landfill awareness should be prioritised in all government and private sectors to instil awareness in the public and reduce cigarette littering behaviour (Sengupta et al., 2010). It is shown that, generally, environmental awareness is a strong driver in achieving environmental goals (Mathiyazhagan, et al., 2018). For instance, awareness of nearby participation has proven large and favourable impact on customer intention to use renewable energy with low impact on the environment (Irfan et al., 2021) and adopt eco-friendly lifestyle behaviours (Cammarelle et al., 2021). Consumers' increased landfill consciousness resulted in improved social-environmental attitudes (Ziadat, 2010). There are programs aimed at raising awareness of the landfill effects of cigarette butts. In this study, landfill awareness was chosen as a predictor that could influence cigarette butts' littering activity (Lamb, 2001). As a result, $\mathrm{H} 2$ is proposed.

H2 Landfill awareness has a significant negative influence on cigarette butts littering behaviour.

Previous research has shown a strong connection between smokers' concerns and their awareness of diseases like heart disease, lung cancer, and blindness (Solberg et al., 1998; Woo \& Au, 2008; Bidwell et al., 2005). Researchers looked into the connection between the concept of customer feared-self and knowledge of smoking-related diseases (Solberg et al., 1998; Woo \& Au, 2008; Bidwell et al., 2005). The act of smoking is not only dangerous to smokers' health, but it is also harmful to the environment concerning landfill activities (Healton et al., 2011). Users are also concerned about tobacco usage and cigarette butt disposal in the environment (Puls et al., 2011). As a result, hypothesis H3 indicates that consumers' self-consciousness and landfill awareness are linked to smokers' cigarette butts littering.

H3 There exists a congruity between feared-self and consumers' landfill awareness.

Purchase decisions are heavily influenced by a consumer's self-concept (Sirgy \& Samli, 1985; Kressmann et al., 2006). Congruence or matching is the result of a consumer's 
self-concept and awareness coming together (Sirgy et al., 1991). "The degree to which one's personality matches one's actions in a specific situation" identifies the congruence construct (Sherman et al., 2012). Researchers utilised self-concept with the aspects provided in self-congruence theory to examine client purchasing behaviour in a commercial setting (Hong \& Zinkhan, 1995; Polegato \& Bjerke, 2006). Several researchers concluded that the customer's real and desired selves are significantly congruent with the consumer's advertising appearance and have a favourable impact on consumer brand tastes and loyalty (Kressmann et al., 2006). Similarly, Mandilya et al. (2020) demonstrate that a consumer with low materialism and a positive attitude towards both environmental sustainability and environmental advertising is more likely to buy environmentally sustainable products in order to have eco-friendly impact on the environment. In a marketing setting, consumer congruence between self-concept and product image is examined (Chon, 1992; Li, 2009; Quan \& Wang, 2004). Congruity has a significant impact on consumer satisfaction, according to prior studies. From the literature evidence, $\mathrm{H} 4$ could be derived as follows:

H4 There is a significant negative impact of feared self and landfill awareness congruence on cigarette butts littering behaviour.

In summary, the four research hypotheses formulated above have been integrated into a research model (Fig. 1).

\section{Methodology}

\subsection{Data collection}

The current study was completed using a quantitative analysis approach. Quantitative analysis allows researchers to put a current or newly established hypothesis to the test (Bryman, 2016). Because the study needed to validate the impact of feared self, landfill awareness, and congruency on cigarette butt littering activity, a quantitative technique was acceptable.

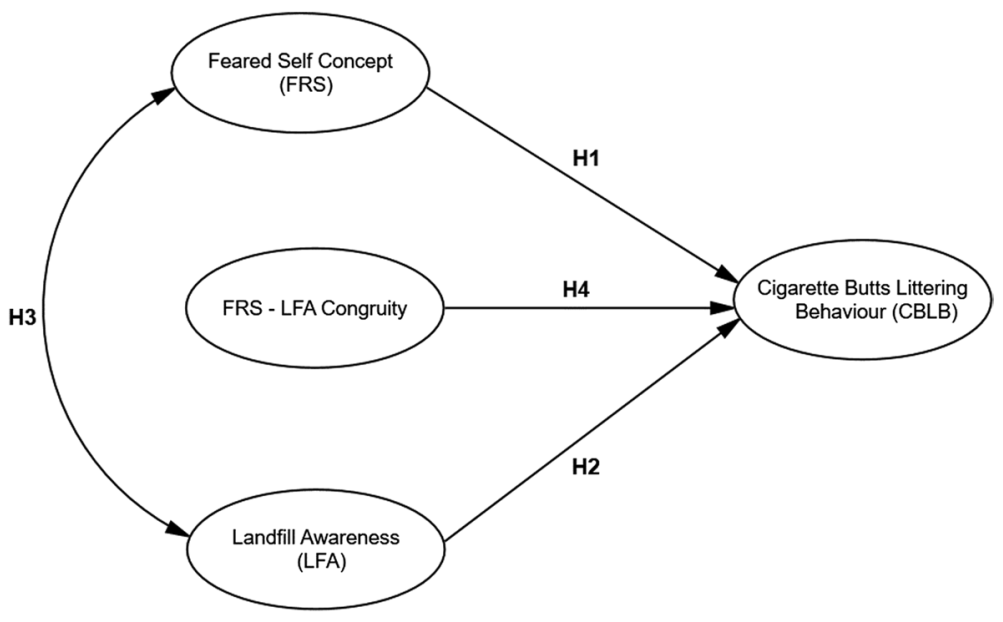

Fig. 1 Conceptual framework and hypotheses 
To collect data from smokers, a cross-sectional survey approach was adopted, with temporal grouping in mind. Purposive sampling was used to select Sarawak universities from among the major universities in Malaysia, as the cigarette consumers here can provide information related to queries. A self-administered survey $(n=1600)$ was organised and performed. A study of smokers aged 18 and older from three institutions was done due to the excessive tobacco consumption among university students (Tamim et al., 2003). Students from three major universities in Kuching, Sarawak, East Malaysia (UNIMAS, MARA University of Technology-UiTM, and Swinburne University) provided data on the study's variables. The questionnaire's pre-adopted edition was written in English and translated into Bahasa Malaysia. Back translation later confirmed the content of each concept employed in the questionnaire (Son, 2018). Both statistical tools were carried out using two type of software: (1) the Statistical Package for Social Science (SPSS) version 20 and (2) Analysis of Moment Structures (AMOS) version 21. SPSS software was used for data cleaning, descriptive statistics, and exploratory factor analysis. AMOS was used for primary research, such as correlation and regression. In such cases where the study hypothesis examines the associations between variables and the strengths of these associations, multivariate regression is a suitable method of data analysis. Structural equation modelling is an effective method for multivariate regression for both research confirmative and exploratory issues (Centobelli et al., 2019; Ho, 2006). There are two significant covariance-based (CB-SEM) and partial least square (PLS-SEM) methods of conducting SEM (Batista-Foguet et al., 2019; Hair et al., 2011). The most suitable method depends on the study objectives and the nature of the data collected. Due to the sample size, concept model novelty, and analysis of models focused on exploring and predicting associations among a series of constructs relatively small, PLS-SEM was considered the most suitable, as recommended by Hair et al. (2011). They have developed a method of testing latent continuous variables by producing multiple indicator variables to investigate the interactive relationship between latent variables (Li et al., 1998). SEM models consist of two main categories: manifest variables (measured in the questionnaire) and latent variables, which show the structures underlying manifest variables (Ho, 2006). As a result, the breadth and integrity of the indicator domain are crucial for ensuring an adequately covered structure and capturing all aspects (Hair et al., 2011).

\subsection{Common method bias test}

Furthermore, common method bias was validated following Gligor (2016), and Lii \& Kuo (2016). To evaluate common method bias, researchers used Harman's one-factor test (Podsakoff et al., 2003; Zu et al., 2010). Exploratory factor analysis (EFA) was used in this study to look at all of the observed variables (Yarimoglu \& Binboga, 2019). According to Podsakoff \& Organ (1986), common bias is eliminated when (1) EFA extracts a single factor that encompasses all variables, or (2) the first extracted factor accounts for the bulk of the total variance (i.e. a value equal or above 0.50). In our case, the EFA discovered five unique variables with eigenvalues larger than 1.0 and a total variance of 66.13 per cent. The first extracted component accounted for 34.09 per cent of the variance, or less than 0.50 per cent of the total variance. The results indicated that both criteria had not been met and that the study had no common method bias.

Furthermore, when the source of bias was not identified a priori, researchers used the single-method-factor methodology established by Podsakoff et al. (2003) and Podsakoff et al. (2005) to validate this conclusion. As a result, we used confirmatory factor analysis 
(CFA) to generate two models: one with and one without a single shared component. The regression weights of both models ranged from 0.146 to 0.195 for feared self, 0.065 to 0.178 for landfill awareness, 0.118 to 0.173 for cigarettes butts littering behaviour, 0.078 to 0.181 for congruency, and showed no statistically significant differences. Doluca et al. (2017) suggested a threshold (0.2) for standardised regression weight differences. Common method bias is not a concern in this study, according to the data (Podsakoff et al., 2003).

\subsection{Measures}

The survey utilised in our study, which includes the measures in "Appendix", was created using questionnaires culled from the literature. Previous research used a 5-point Likert scale with a Cronbach's alpha of 0.81 as a metric for feared self, landfill awareness, and cigarette butts littering behaviour (Davidson, 2000; Mollema et al., 2000; Smith et al., 2011).

Rath et al. (2012) developed a customer landfill awareness instrument to assess cigarette littering behaviour: it had seven items with a 5-point Likert scale ranging from strongly disagree (1) to strongly accept (5), and the remainder were dichotomous ( $\mathrm{No} / \mathrm{Yes})$. With a Cronbach's alpha of 0.85 , the scale was considered stable.

Rath et al. (2012) adapted a 5-point Likert scale for cigarette butts littering activity that was used to anchor all things of the feared self and landfill awareness scale: it had a reliability of 0.71 Cronbach's alpha. Ericksen (1996) established the following equation for measuring the congruence between consumer feared self-concept and landfill awareness in this study:

$$
\text { FESLFA }_{K}(\text { Congruence })=\sum_{i=1}^{n}\left|\mathrm{LFA}_{i k}-\mathrm{FES}_{i k}\right|
$$

Congruence $_{\mathrm{k}}=$ Feared Self Landfill Awareness Congruity score for respondent $(\mathrm{k}) \cdot \mathrm{KFA}_{\mathrm{ik}}$ $=$ Landfill Awareness score of respondents $(k)$ along with the item $(i) \cdot \mathrm{FES}_{\mathrm{ik}}=$ Feared Selfscore of respondents $(k)$ along with the item $(i)$.

\subsection{Pilot test one}

A complete version of the questionnaire was distributed to the 50 respondents in Kuching, Sarawak, Malaysia. This pilot test had three objectives: firstly, to evaluate comprehensibility and clarity of the indicators which were in the instrument; secondly, to examine the time required to fill out the questionnaire by respondents; and thirdly, to test the internal reliability of the measure. There was a portion at the end of the questionnaire for personal opinions on needed improvement.

\subsection{Pilot test two}

Two questions were modified based on the suggestion provided by the respondents as highlighted earlier in pilot test one. At this stage, the modified questionnaire was distributed to another 50 different respondents. The objective of this second pilot study was to identify the reliability and validity of the items and constructs by testing Cronbach's alpha. The reliability and validity of all the measures observed with a strong reliability with Cronbach's alpha 0.7 before conducting the survey for the main study are shown in Table 1. 
Table 1 Reliability for Pilot Test I and II

\begin{tabular}{lllc}
\hline Constructs & $\begin{array}{l}\text { Alpha reliability value for Pilot } \\
\text { test I }(\mathrm{N}=50)\end{array}$ & $\begin{array}{l}\text { Alpha reliability value for Pilot- } \\
\text { test II (N=30) }\end{array}$ & $\begin{array}{l}\text { Number } \\
\text { of items }\end{array}$ \\
\hline Feared self & 0.79 & 0.78 & 7 \\
Landfill awareness & 0.81 & 0.77 & 6 \\
$\begin{array}{l}\text { Cigarette butts littering } \\
\text { behaviour }\end{array}$ & 0.77 & 0.79 & 4 \\
\hline
\end{tabular}

\section{Analysis and results}

This study depends upon a self-administered questionnaire. Hence, response error was an issue that is not under the researcher's control as stated by Highman (1955). Therefore, the applicable data screening techniques as descriptive statistics, treatment of missing data and detection of outliers are discussed in this section. The data were collected from smokers of universities students in Sarawak, Malaysia. A total of 1600 questionnaires were distributed in these four major universities of Sarawak. There were 446 questionnaires found to be incomplete, and responses that were more than $5 \%$ incomplete in the questionnaire were disqualified from the sample size of this study. After screening the data, 1072 responses were obtained. The percentage of those that responded was 67\% (Malhotra \& Grover, 1998; O'Leary-Kelly \& Vokurka, 1998). According to Ding et al. (1995), the minimal sample size for assessing the research framework and testing the research hypotheses using a SEM technique should be between 100 and 150 .

Data normality is a basic assumption for SEM. Several steps were carried out for the normality of the data. Three methods were used to ascertain the normality of the data, namely Q-Q plots, Skewness and Kurtosis calculation and Kolmogorov-Smirnov test (Hair et al., 2011). Outliers were detected with the help of Box Plot after the screening process in this study. The outliers appeared within the one per cent of prescribed limits. On that basis, no re-coding was required. Hence, all the 1072 responses of each construct were converted into standard $143 \mathrm{Z}$-scores, and further outliers were identified. In this study, 93 responses were accounted as outliers within the prescribed limit. Subsequently, 979 responses were calculated after removing the univariate outliers. After transforming the data into standardised Z-Score, all the values were found in the range of -3 and +3 , such as from -2.93 to 2.64 , as suggested by Tabachnick \& Fidell (2007). Hence, the values being in the field ensured that the data in hand have a normal distribution in this study.

\section{Respondents' profile}

In order to sample the demographics, respondents' characteristics were varied widely (Morgan \& Hunt, 1994). In this study, the profile of respondents consisted of five variables such as gender, age, education, ethnicity, and religion. In this study, demographic information has no impact on the level of analysis, which provides a general view concerning gender, age, current marital status, number of family members living at home, highest education completed, ethnic group, religion, and income participation. The results of all the profile variables are summarised in Table 2. 
Table 2 Respondent profile

\begin{tabular}{|c|c|c|c|}
\hline \multicolumn{2}{|l|}{ Variables } & \multirow{2}{*}{$\begin{array}{l}\text { Number } \\
565\end{array}$} & \multirow{2}{*}{$\begin{array}{l}\text { Percentage }(\%) \\
57.71\end{array}$} \\
\hline Gender & Female & & \\
\hline & Male & 414 & 42.29 \\
\hline & Total & 979 & 100 \\
\hline \multirow[t]{8}{*}{ Age } & Less than 20 & 61 & 6.23 \\
\hline & 21-25 Years & 298 & 30.44 \\
\hline & 26-30 Years & 395 & 40.35 \\
\hline & 32-35 Years & 80 & 8.17 \\
\hline & $36-40$ Years & 93 & 9.50 \\
\hline & $41-45$ Years & 27 & 2.76 \\
\hline & 46-50 Years & 11 & 1.12 \\
\hline & Above 51 Years & 14 & 1.43 \\
\hline \multirow[t]{6}{*}{ Education } & High School or Less & 386 & 39.43 \\
\hline & Bachelor degree & 463 & 47.29 \\
\hline & Master & 72 & 7.35 \\
\hline & Doctorate & 25 & 2.55 \\
\hline & Other & 33 & 3.37 \\
\hline & Total & 979 & 10 \\
\hline \multirow[t]{9}{*}{ Ethnicity } & Malay & 456 & 46.58 \\
\hline & Indian & 18 & 1.84 \\
\hline & Chinese & 281 & 28.79 \\
\hline & Iban & 68 & 6.95 \\
\hline & Melanau & 35 & 3.58 \\
\hline & Orang Ulu & 45 & 4.60 \\
\hline & Bidayuh & 34 & 3.47 \\
\hline & Other & 42 & 4.29 \\
\hline & Total & 979 & 100 \\
\hline \multirow[t]{6}{*}{ Religion } & Muslim & 458 & 46.78 \\
\hline & Hindu & 18 & 1.84 \\
\hline & Christian & 319 & 32.58 \\
\hline & Buddhist & 158 & 16.14 \\
\hline & Other & 26 & 2.66 \\
\hline & Total & 979 & 10 \\
\hline
\end{tabular}

\subsection{Exploratory factor analysis (EFA)}

Kim \& Muller (1978) explained EFA as "a variety of mathematical methods whose common purpose is to interpret a series of variables in terms of a smaller number of hypothetical variables". The EFA attempts to limit the dimensionality of variables by grouping those that have a high similarity with each other in variables (Tabachnick \& Fidell, 2007; Joliffe \& Morgan, 1992). The principal component analysis (PCA) is the most commonly used predictive analysis tool, and it is part of the EFA. PCA is a technique for reducing the dimensions of a set of continuous variables (Bryant \& Yarnold, 1995). The PCA aims to minimise the amount of data required for determining the variables that lead to more significant variance in this study. As a result, when conducting an EFA on our collected results, we used a basic PCA with no rotation as an extraction tool. And there are no hard 
and fast rules for whether or not to use rotation or what type of rotation to use. The aim of using rotation, or a specific form of rotation, according to Brown (2009), is to expose a basic structure that makes it easier to understand the extracted variables. Until a simple structure has been discovered, rotation is not necessary. As a result, the variables were standardised using the SPSS version 23 program before running the PCA.

To determine the appropriate number of aspects, this study used EFA with principal axis factoring (PAF) extraction and the Varimax system of rotation for six items of feared selves, seven items of landfill awareness, and four items of cigarette butts littering behaviour constructs. The association between the FRS_5 elements of feared self was much weaker, which was less than 0.3 (Field, 2009). As a result, the feared self item FRS_5 was omitted from further data processing. The factor loadings for the remaining items were greater than 0.5 (Hair et al., 1998). Commonly, there are four methods that verify a data matrix to see whether the present data matrix can support the factor analysis.

The assessment of the correlation matrix indicates that a suitable correlation exists within the data matrix. The low correlations throughout a correlation matrix indicate that factor analysis is inappropriate (Stewart, 1981). Hardy and Bryman (2009) stated that the correlation matrix has cut-off values to indicate its appropriateness for factor analysis-a correlation range from 0.10 to 0.30 is considered appropriate and inappropriate if less than that inappropriate (Hardy and Bryman, 2009). Pallant (2007) recommended that when significant correlations are more than 0.30 within a data matrix, then time factor analysis has its applicability. Otherwise, the data matrix cannot be accepted for factor analysis.

The anti-image correlation matrix means that a partial correlation has a negative value (Brace et al., 2006). When the influence of other variables is accounted for, a partial correction between variables is unexplainable. Therefore, high partial correlations indicate that the data matrix has high unexplained correlations (Hair et al., 2011). Namely, there is no adequate latent factor (Brace et al., 2006). The lowest anti-image correlations indicate that a data matrix is suitable for factor analysis (Field, 2009; Tabachnick \& Fidell, 2007).

Bartlett's test of sphericity is a statistical test that analyses either a correlation matrix has meaningful correlation among the variables or not (Hinton et al., 2004). The computation of Bartlett's test of sphericity is based on the following equation:

$$
-\left[(N-1)-\left(\frac{2 P+5}{6}\right)\right] \log e^{|R|}
$$

$\mathrm{N}$ is the sample size. $\mathrm{P}$ is the number of variables and. $|R|$ is the determinant of the correlation matrix.

Hinton et al. (2004) and Pallant (2007) highlighted that when Bartlett's test of spherical is statistically significant at sig. $<0.05$, there exists sufficient correlation among the variables to implement factor analysis in a data matrix. Furthermore, the data matrix is not suitable for factor analysis. According to that, this study passed the criteria of Bartlett's test.

According to Stewart (1981), the Kaiser-Meyer-Olkin measure of sampling adequacy is an index that quantifies the intensity of inter-correlations among the variables. To calculate the Kaiser-Meyer-Olkin, the following equation is used:

$$
M S A=\frac{\sum \sum_{j \neq k} r_{j k}^{2}}{\sum \sum_{j \neq k} r_{j k}^{2}+\sum \sum_{j \neq k} q_{j k}^{2}}
$$

$r_{j k}^{2}=$ Square of the off-diagonal elements of the original correlations. $\boldsymbol{q}_{j k}^{2}=$ Square of the off-diagonal anti-image correlation matrix. 
The range of Kaiser-Meyer-Olkin measure of sampling adequacy value is from 0 to 1. When Kaiser-Meyer-Olkin measure of sampling adequacy value is reached at 1 , it shows that variables are entirely predicted without any error from the other variables. Kaiser \& Rice (1974) stated that the data matrix is suitable for factor analysis using the Kaiser-Meyer-Olkin measure of sampling adequacy.

\subsection{Confirmatory factor analysis (CFA)}

The reliable, convergent, and discriminant validity of the constructs feared self, landfill awareness, and consumer cigarette butts littering behaviour were examined using a structural model. As proposed by Anderson \& Gerbing (1988) and Werts et al. (1974), composite reliability (C.R) was used to determine the accuracy of the constructs. Several scholars (Nunnally \& Bernstein, 1994; Mollema et al., 2000) proposed a composite reliability cut-off value of greater than 0.70 . As seen in Table 1 , composite reliability ranges from 0.884 to 0.912 .

The observed variables of feared self, landfill awareness, cigarette butts littering behaviour had substantial factor loading, and average variance extracted (AVE) was used to assess convergent validity. With $t$ values ranging from 3.56 to 79.42 , factor loadings are greater than 5.7 and important $(p<0.01)$. However, factor loading of all observable variables for latent variables is important, so AVE is greater than 0.50 (Table 1), indicating that latent variables such as feared self, landfill awareness, and cigarette butts littering behaviour have convergent validity (Fornell \& Larcker, 1981).

The diagonal value of the correlational matrix is assumed to be greater than the offdiagonal value for appropriate discriminant validity (DV) (Barclay et al., 1995). The diagonal value of the individual latent variable, on the other hand, was greater than the off-diagonal factor, indicating strong DV in this study, as seen in Tables 3, 4.

\subsection{Results of hypothesis testing}

The r-square value was used to measure the relationship between feared self and Landfill perception. With the aid of a structural model, the impact of feared self, environmental awareness, and congruence of feared self and landfill awareness on cigarette butts littering behaviour was studied using standardised path coefficient $(\beta)$ and significance level (t-statistics). Table 5 and Fig. 2 demonstrate the impact.

Out of four hypotheses with large beta values, one was accepted in light of the structural model. $\mathrm{Hl}$ was rejected with a value of 0.36 and a $p$-value of 0.000 , indicating that fear of self does not substantially negatively impact customer cigarette butts littering. Similarly, at $=0.39$ and $\mathrm{p}=0.000, H 2$ was not supported by the results. $H 2$ is also evaluated until the congruence is tested. It found substantial $r=0.65$ and $p=0.000$ values, confirming the structural model's significant correlation. The high worth of $r$ suggested that consumers feared self of landfill awareness is strongly linked together. As a result, the $\mathrm{H} 3$ result is consistent with the findings of many studies (Woo \& Au, 2008; Gould et al., 2015). $H 4$ had a significant finding of $\beta=0.512$ and $p=0.000$, indicating that the congruity between feared self and landfill awareness has affected cigarette butts littering behaviour. 
Table 3 Summary of the measurement model

\begin{tabular}{|c|c|c|c|c|c|}
\hline Items & Standardised Loadings & $t$-value & Constructs & AVE & C.R \\
\hline FRS_1 & 0.76 & $19.11 * * *$ & \multirow[t]{5}{*}{ Feared Self } & \multirow[t]{5}{*}{0.604} & \multirow[t]{5}{*}{0.884} \\
\hline FRS_2 & 0.85 & $20.72 * * *$ & & & \\
\hline FRS_3 & 0.77 & $18.31 * * *$ & & & \\
\hline FRS_4 & 0.71 & $19.27 * * *$ & & & \\
\hline FRS_6 & 0.79 & $24.38 * * *$ & & & \\
\hline LFA_1 & 0.71 & $14.18 * * *$ & \multirow[t]{6}{*}{ Landfill Awareness } & \multirow[t]{6}{*}{0.635} & \multirow[t]{6}{*}{0.912} \\
\hline LFA_2 & 0.77 & $12.11 * * *$ & & & \\
\hline LFA_3 & 0.81 & $18.37 * * *$ & & & \\
\hline LFA_4 & 0.88 & $15.86^{* * *}$ & & & \\
\hline LFA_5 & 0.79 & $13.54 * * *$ & & & \\
\hline LFA_6 & 0.81 & $10.51 * * *$ & & & \\
\hline CBLB_1 & 0.68 & $13.31 * * *$ & \multirow{5}{*}{$\begin{array}{l}\text { Cigarette Butts Litter- } \\
\text { ing Behaviour }\end{array}$} & \multirow[t]{5}{*}{0.650} & \multirow[t]{4}{*}{0.880} \\
\hline CBLB_2 & 0.84 & $18.11 * * *$ & & & \\
\hline CBLB_3 & 0.81 & $14.10 * * *$ & & & \\
\hline CBLB_4 & 0.88 & $12.04 * * *$ & & & \\
\hline \multicolumn{4}{|c|}{ Achieved Fit Indices } & & \\
\hline & $\mathrm{CMIN} / \mathrm{DF}(\times 2 / \mathrm{df})$ & RMSEA & TLI & GFI & CFI \\
\hline Final values & $3.8245(415.288 / 246)$ & 0.078 & 0.928 & 0.991 & 0.917 \\
\hline
\end{tabular}

FRS, Feared Self, LFA, Landfill Awareness, CBLB Cigarette Butts Littering Behaviour, C.R Composite Reliability, $A V E$ Average Variance Extracted

Table 4 The discriminant validity summary

\begin{tabular}{llll}
\hline & FRS & LFA & CBLB \\
\hline FRS & 0.604 & & \\
LFA & 0.51 & 0.81 & \\
CBLB & 0.582 & 0.71 & 0.68 \\
\hline
\end{tabular}

FRS Feared Self, LFA Landfill Awareness, CBLB Cigarette Butts Littering Behaviour

\section{Discussion}

According to consumer research, the impact of actual and ideal self-congruence differs depending on the behavioural domain, therefore it must be validated each time (Huber et al., 2018; Zhu et al., 2019). Based on the earlier contributions, it was predicted that H1, H2, and H4 would be confirmed (Mollema et al., 2000; Davidson, 2000; Smith et al., 2011; Rath et al., 2012). Previous studies on the links and congruence between feared-self, landfill awareness, and cigarette butts littering behaviour, however, disputed the findings. Contrary to previous research, it was observed that the construct of fearedself had a beneficial impact on cigarette butts littering behaviour, and that the congruence of the feared self and landfill knowledge did not help reduce cigarette butts littering behaviour (Gatersleben et al., 2019; Mathiyazhagan et al., 2018). Recent studies examined the moderating effect of social awareness (Kaufmann et al., 2016; Mathiyazhagan 


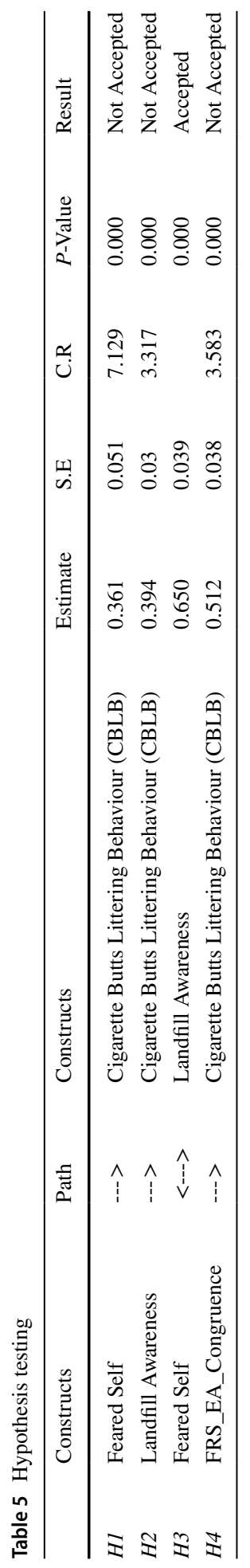




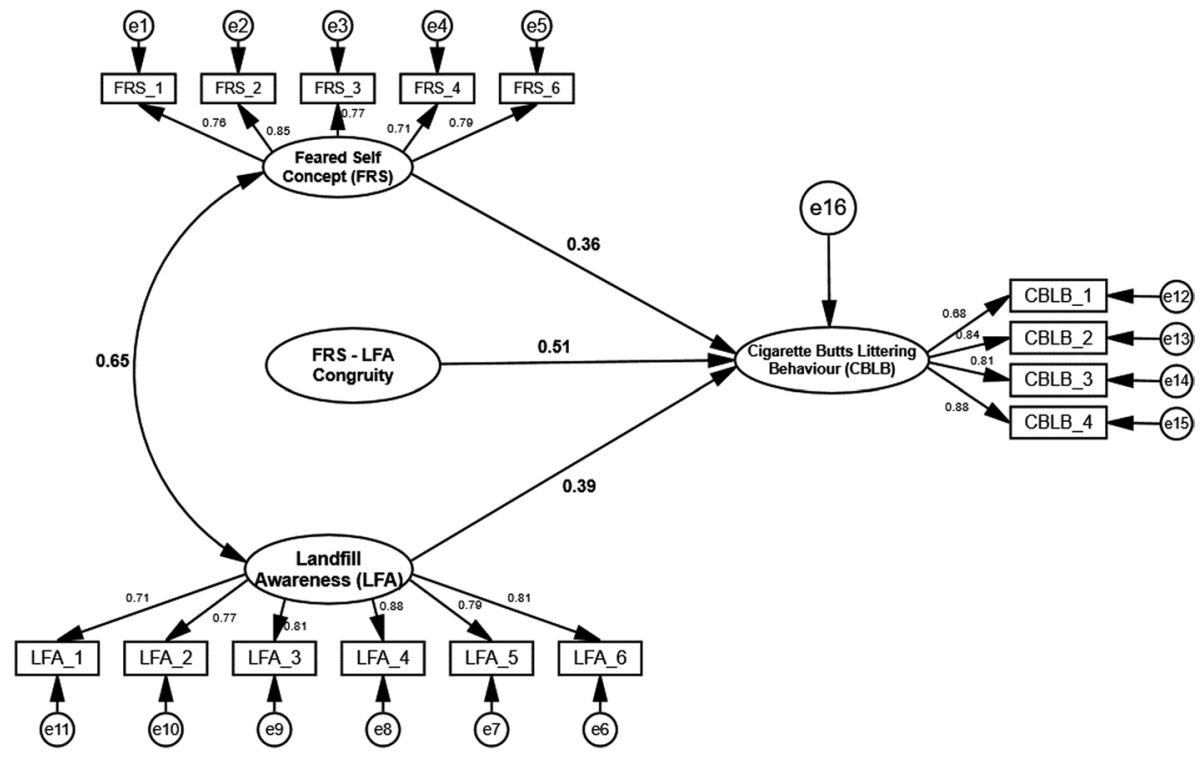

Fig. 2 Structural model

et al., 2018; Zogaj et al., 2021), and this effect was consistent with previous research findings (Baptiste, 2008; Kollmuss \& Agyeman, 2002; Kollmuss \& Agyeman, 2002; Rasool et al., 2021; Xu et al., 2013). As for the originality of our research outcomes, they shed new light on the landfill awareness context by demonstrating that it is occasionally a strong driver. This aspect could be connected to the nature of the respondents. The survey participants are represented by university students who may be unable to recognise or understand the impact of the feared self on cigarette butts littering behaviour. The scared selves of young university students were not receptive enough to lessen the negative repercussions of cigarette butts littering behaviours. The threat of negative consequences from cigarette butts littering may outweigh the social or peer normative impact. People's perceptions, as well as a misalignment between people's and society's expectations regarding the activity, lead to youth engaging in risky behaviours (Smith \& McDaniel, 2011; Mead et al., 2014).

According to the principle of reasoned action, individuals' incentive to accept a supposed norm alters the effect of the standard on associated perceptions and actions (Montano \& Kasprzyk, 2015). The force of social exposure, or the signals that an individual receives from his or her physical, social, and symbolic settings, is a distinct source of knowledge that transmits norms and molds consumers' attitudes and behaviours secondary (Chearskull, 2010; Nunnally, 1994).

According to the acceptance theory, the feared self and landfill perception are linked (H3). However, the level of consumer agreement is insufficient to recognise the fear of the detrimental impacts of cigarette butts littering and the implications for the environment. Fear-based advertising is effective in lowering consumer smoking and littering (Tannenbaum et al., 2015). In conclusion, the results demonstrate that combining scared self and landfill knowledge has a bigger impact on consumers' cigarette butts littering behaviour than either feared self or landfill awareness alone. 


\section{Conclusions and implications}

This study looked into the impact of consumers' feared self and consumer landfill awareness on cigarette butts littering behaviour, as well as the relationships between consumers' feared self and landfill awareness and the impact of congruence between feared self and landfill awareness on consumer cigarette butts littering behaviour. In the past, fear has been used to persuade people to quit smoking (Laroche et al., 2001). Recent research reveals that by emphasising the negative consequences of one's activities that jeopardise one's ability to regard oneself favourably, the effectiveness of such anxiety appeals can be improved (Memish et al., 2017). Previous research looked at whether a self-concept may be compatible with a product image, brand image, or personality (Hosany \& Martin, 2012). However, no analysis of self-concept centred on feared self and landfill information, particularly involving cigarette butts littering behaviour, has been undertaken utilising the self-congruence theory (Al-Khatib et al., 2009; Slaughter et al., 2010). The study showed feared-self and landfill awareness, feared-self and cigarette butts littering behaviour, landfill awareness, and cigarette butts littering behaviour. A major commitment of this research is the presence of congruence between feared-self and landfill consciousness. The feared-predicted self's response to landfill awareness, however, was insufficient to reduce cigarette butts littering behaviour among consumers, according to data analysis and interpretation.

The current results clearly show that litter begets litter. This finding is not new, and indeed, it was noted in the early studies of littering (e.g., Cialdini et al., 1990; Keizer et al., 2008). The results of this study suggest several litter prevention strategies. These strategies combine structural and motivational activities. Waste managers should therefore include a cognitive solution to litter prevention. Researchers are consequently recommended to participate in the design of litter prevention strategies. This aspect ensures that behavioural problems are taken into account in such scenarios. There is the possibility to create anti-littering measures. As a result, even if individuals are willing and determined to behave correctly, they are constrained by circumstances (e.g. lack of adequate facilities). This aspect suggests additional studies to investigate the role of situational limitations in litter behaviour specifically. In the light of what has been highlighted so far, we suggest what could be valuable ideas for new research and a new implementation of strategies to tackle the phenomenon. It has already been indicated above that a considerable effort should be carried out to address the problem of littering cigarettes. In this case, a more significant presence of public ashtrays and an intense use of raising awareness could represent practical measures to reduce the phenomenon and mitigate the damage. In addition, the idea of inserting or enhancing the presence of anti-littering messages, textual or sign, could be considered, inviting the consumer to act correctly.

In addition, the improvement of the cleaning and collection system can certainly make the places where it is implemented cleaner; however, it hides a possible undesirable effect. With a better collection system, those who accept littering can relax their guard, knowing that their waste will only be left in the environment for a short time. The strengthening of road litter bins would counteract the phenomenon, especially those currently lacking or not served in a way that is not adequate for the needs. However, even in this case, it is not uncommon to find waste abandoned outside the bins. As for the awareness campaign, it could appear to be an educational way that is useful only for training children or young people of school age, contrary to how adults would accept it. 
Indeed, without diminishing the potential effectiveness of the educational intervention dedicated to the youngest, we suggest evaluating solutions aimed at raising awareness of the phenomenon also towards adults since many are not fully informed on the issue.

\section{Appendix: Measurement instrument}

\begin{tabular}{|c|c|c|c|c|}
\hline Construct & Item name & Remark & Item & Source \\
\hline \multirow[t]{6}{*}{ Feared Self } & FRS_1 & Omitted & $\begin{array}{l}\text { I am afraid of disaster in the } \\
\text { world }\end{array}$ & \multirow{6}{*}{$\begin{array}{l}\text { Davidson (2000) Mollema } \\
\text { et al. (2000); Smith et al. } \\
\text { (2011) }\end{array}$} \\
\hline & FRS_2 & & $\begin{array}{l}\text { I am bothered by doing the } \\
\text { wrong thing in front of me, }\end{array}$ & \\
\hline & FRS_3 & & $\begin{array}{l}\text { am afraid of doing something } \\
\text { when people might be watch- } \\
\text { ing }\end{array}$ & \\
\hline & FRS_4 & & $\begin{array}{l}\text { Fear of something bad's conse- } \\
\text { quences making me scares }\end{array}$ & \\
\hline & FRS_5 & & $\begin{array}{l}\text { When I have to do illegal work, } \\
\text { I get restless due to its bad } \\
\text { effect on society }\end{array}$ & \\
\hline & FRS_6 & & $\begin{array}{l}\text { When I have to dispose of my } \\
\text { cigarette butt on ground, } \\
\text { sewer/gutter, I get fear of its } \\
\text { result }\end{array}$ & \\
\hline \multirow[t]{7}{*}{ Landfill Awareness } & LFA_1 & Omitted & $\begin{array}{l}\text { The single most collected items } \\
\text { in beach waste cleanup each } \\
\text { year is: beverage containers, } \\
\text { cigarette butts, fishing nets, } \\
\text { plastic bags }\end{array}$ & \multirow[t]{7}{*}{ Rath et al. (2012) } \\
\hline & LFA_2 & & Cigarette butts are toxic & \\
\hline & LFA_3 & & $\begin{array}{l}\text { Cigarette butts are biodegrad- } \\
\text { able }\end{array}$ & \\
\hline & LFA_4 & & $\begin{array}{l}\text { Cigarette butts are harmless } \\
\text { when eaten by humans }\end{array}$ & \\
\hline & LFA_5 & & $\begin{array}{l}\text { Cigarette butts are harmless } \\
\text { when eaten by animals/ } \\
\text { marine life }\end{array}$ & \\
\hline & LFA_6 & & $\begin{array}{l}\text { It can be dangerous to throw a } \\
\text { cigarette butt in a trashcan }\end{array}$ & \\
\hline & LFA_7 & & $\begin{array}{l}\text { Cigarette butts are considered } \\
\text { to be litter }\end{array}$ & \\
\hline
\end{tabular}




\begin{tabular}{|c|c|c|c|}
\hline Construct & Item name & Item & Source \\
\hline \multirow[t]{4}{*}{$\begin{array}{l}\text { Cigarette Butt Lit- } \\
\text { tering Behaviour }\end{array}$} & CBLB_1 & $\begin{array}{l}\text { Did you ever dispose of your } \\
\text { cigarettes in the way? }\end{array}$ & Rath et al. (2012) \\
\hline & CBLB_2 & $\begin{array}{l}\text { Did you ever dispose of your } \\
\text { cigarette butt in the car and } \\
\text { throw them out from the car } \\
\text { window? }\end{array}$ & \\
\hline & CBLB_3 & $\begin{array}{l}\text { Did you ever dispose of your } \\
\text { cigarette butt on the ground, } \\
\text { in the sewer/gutter or down } \\
\text { a drain? }\end{array}$ & \\
\hline & CBLB_4 & $\begin{array}{l}\text { Do you prefer to waste your } \\
\text { cigarette butt on the public } \\
\text { ashtray? }\end{array}$ & \\
\hline
\end{tabular}

Funding Open access funding provided by Università Parthenope di Napoli within the CRUI-CARE Agreement.

Open Access This article is licensed under a Creative Commons Attribution 4.0 International License, which permits use, sharing, adaptation, distribution and reproduction in any medium or format, as long as you give appropriate credit to the original author(s) and the source, provide a link to the Creative Commons licence, and indicate if changes were made. The images or other third party material in this article are included in the article's Creative Commons licence, unless indicated otherwise in a credit line to the material. If material is not included in the article's Creative Commons licence and your intended use is not permitted by statutory regulation or exceeds the permitted use, you will need to obtain permission directly from the copyright holder. To view a copy of this licence, visit http://creativecommons.org/licenses/by/4.0/.

\section{References}

Aaker, J. L., \& Lee, A. Y. (2001). "I" seek pleasures and "we" avoid pains: The role of self-regulatory goals in information processing and persuasion. Journal of Consumer Research, 28(1), 33-49. https://doi. org/10.1086/321946

Abdul-Wahab, S. A. (2006). Impact of fugitive dust emissions from cement plants on nearby communities. Ecological Modelling, 195(3-4), 338-348. https://doi.org/10.1016/j.ecolmodel.2005.11.044

Al-Khatib, I. A., Arafat, H. A., Daoud, R., \& Shwahneh, H. (2009). Enhanced solid waste management by understanding the effects of gender, income, marital status, and religious convictions on attitudes and practices related to street littering in Nablus-Palestinian territory. Waste Management, 29(1), 449455. https://doi.org/10.1016/j.wasman.2008.02.004

Anderson, J.C., \& Gerbing, D.W. (1988). An updated paradigm for scale development incorporating unidimensionality and its assessment. Journal of Marketing Research, 25(2), 186-192. https://doi.org/10. $1177 / 002224378802500207$

Back, K. J. (2005). The effects of image congruence on customers' brand loyalty in the upper middle-class hotel industry. Journal of Hospitality \& Tourism Research, 29(4), 448-467. https://doi.org/10.1177/ 1096348005276497

Baptiste, A. K. (2008). Evaluating environmental awareness: A case study of the nariva swamp, trinidad. State University of New York College of Environmental Science and Forestry.

Barclay, D., Higgins, C., \& Thompson, R. (1995). The partial least squares (PLS) approach to casual modeling: personal computer adoption and use as an Illustration.

Batista-Foguet, J. M., Saris, W., Boyatzis, R. E., Serlavós, R., \& Moreno, F. V. (2019). Multisource assessment for development purposes: Revisiting the methodology of data analysis. Frontiers in Psychology, 9(1), 2646. https://doi.org/10.3389/fpsyg.2018.02646

Belk, R. W. (1988). Possessions and the extended self. Journal of Consumer Research, 15(2), 139-168.

Bidwell, G., Sahu, A., Edwards, R., Harrison, R. A., Thornton, J., \& Kelly, S. P. (2005). Perceptions of blindness related to smoking: A hospital-based cross-sectional study. Eye, 19(9), 945. https://doi.org/ $10.1038 /$ sj.eye. 6701955 
Birdwell, A. E. (1968). A study of the influence of image congruence on consumer choice. The Journal of Business, 41(1), 76-88.

Brown, J. D. (2009). Choosing the right number of components or factors in PCA and EFA. Shiken: JALT Testing \& Evaluation SIG Newsletter, 13(2), 19-23.

Bryant, F. B., \& Yarnold, P. R. (1995). Principal component analysis and exploratory and confirmatory factor analysis. In: L. G. Grimm, \& P. R. Yarnold (Eds.), Reading and understanding multivariate statistics (pp. 99-136). Washington DC: American Psychological Association.

Bryman, A. (2016). Social research methods. Oxford University Press.

Cammarelle, A., Viscecchia, R., \& Bimbo, F. (2021). Intention to purchase active and intelligent packaging to reduce household food waste: Evidence from Italian consumers. Sustainability (switzerland), 13(8), 4486.

Carver, C. S., \& Scheier, M. F. (2001). On the self-regulation of behaviour. Cambridge University Press.

Carver, C. S., Lawrence, J. W., \& Scheier, M. F. (1999). Self-discrepancies and affect: Incorporating the role of feared selves. Personality and Social Psychology Bulletin, 25(7), 783-792. https://doi.org/10.1177/ 0146167299025007002

Cătălin, M. C., \& Andreea, P. (2014). Brands as a mean of consumer self-expression and desired personal lifestyle. Procedia - Social and Behavioral Sciences, 109, 103-107.

Centobelli, P., Cerchione, R., Esposito, E., \& Shashi, . (2019). The mediating role of knowledge exploration and exploitation for the development of an entrepreneurial university. Management Decision, 57(12), 3301-3320.

Chearskull, P. (2010). An empirical investigation of performance measurement system use and organisational performance (Doctoral Dissertation). Retrieved from Scholar.lib.vt.edu.

Chon, K. S. (1992). The role of destination image in tourism: An extension. The Tourist Review, 47(1), 2-8. https://doi.org/10.1108/eb058086

Cialdini, R.B., Reno, R.R., \& Kallgren, Carl. (1990). A focus theory of normative conduct: Recycling the concept of norms to reduce littering in public places. Journal of Personality and Social Psychology, 58, 1015-1026. https://doi.org/10.1037/0022-3514.58.6.1015

Cope, J. G., Huffman, K. T., Allred, L. J., \& Grossnickle, W. F. (1993). Behavioural strategies to reduce cigarette litter. Journal of Social Behaviour and Personality, 8(4), 607.

Davidson, J. (2000). A phenomenology of fear: Merleau-Ponty and agoraphobic life-worlds: This paper is dedicated to Jim Davidson, 1965-2000. Sociology of Health and Illness, 22(5), 640-660. https://doi. org/10.1111/1467-9566.00224

Dehdari, T. (2020). A qualitative exploration of Iranian smokers' experiences in terms of cigarette butt littering behaviour. International Journal of Environmental Health Research, 1-9.

Derikx, L. M., \& van Lierop, D. (2021). Intentions to participate in carsharing: The role of self-and social identity. Sustainability (switzerland), 13(5), 1-30.

Ding, L., Velicer, W. F., \& Harlow, L. L. (1995). Effects of estimation methods, number of indicators per factor, and improper solutions on structural equation modeling fit indices. Structural Equation Modeling: A Multidisciplinary Journal, 2(2), 119-143. https://doi.org/10.1080/10705519509540000

Dolich, I. J. (1969). Congruence relationships between self images and product brands. Journal of Marketing Research, 6(1), 80-84. https://doi.org/10.1177/002224376900600109

Doluca, H., Wagner, M., \& Block, J. (2017). Sustainability and environmental behaviour in family firms: A longitudinal analysis of environment-Related activities innovation and performance. Business Strategy and the Environment, 27(1), 152-172. https://doi.org/10.1002/bse.1998

Ekinci, Y., \& Riley, M. (2003). An investigation of self-concept: Actual and ideal self-congruence compared in the context of service evaluation. Journal of Retailing and Consumer Services, 10(4), 201-214. https://doi.org/10.1016/S0969-6989(02)00008-5

Ericksen, M. K. (1996). Using self-congruence and ideal congruence to predict purchase intention: A European perspective. Journal of Euro-Marketing, 6(1), 41-56.

Field, A. (2009). Discovering statistics using SPSS. Beverly Hills: Sage Publications.

Fonda, D., Cook, J., Sandler, V., \& Bailey, M. (2006). Sustained reduction in serious fall-related injuries in older people in hospital. Medical Journal of Australia, 184(8), 379-382.

Fornell, C., \& Larcker, D. F. (1981). Structural equation models with unobservable variables and measurement error: Algebra and statistics. https://doi.org/10.1177/002224378101800313

Fransson, N., \& Gärling, T. (1999). Environmental concern: Conceptual definitions, measurement methods, and research findings. Journal of Environmental Psychology, 19(4), 369-382. https://doi.org/10.1006/ jevp.1999.0141

Gatersleben, B., Murtagh, N., Cherry, M., \& Watkins, M. (2019). Moral, wasteful, frugal, or thrifty? Identifying consumer identities to understand and manage pro-environmental behaviour. Environment and Behaviour, 51(1), 24-49. 
Gilbert, P. (1993). Defence and safety: Their function in social behaviour and psychopathology. British Journal of Clinical Psychology, 32(2), 131-153.

Gligor, D. M. (2016). The role of supply chain agility in achieving supply chain fit. Decision Science, 47(3), 524-553.

González-Salgado, I. D. L., Rivera-Navarro, J., Sureda, X., \& Franco, M. (2020). Qualitative examination of the perceived effects of a comprehensive smoke-free law according to neighborhood socioeconomic status in a large city. SSM - Population Health, 11, 100597.

Gould, G. S., Bittoun, R., \& Clarke, M. J. (2015). A pragmatic guide for smoking cessation counselling and the initiation of nicotine replacement therapy for pregnant Aboriginal and Torres Strait Islander smokers. Journal of Smoking Cessation, 10(2), 96-105. https://doi.org/10.1017/jsc.2014.3

Hair, J. F., Black, W. C., Babin, B. J. et al. (1998) Multivariate data analysis,; 5(3): 207-219. Upper Saddle River, NJ: Prentice hall.

Hair, J. F., Ringle, C. M., \& Sarstedt, M. (2011). PLS-SEM: Indeed a silver bullet. Journal of Marketing Theory and Practice, 19(2), 139-152.

Hardy, M. A., \& Bryman, A. (2009) Handbook of data analysis. Thousand Oaks, CA: Sage Publications Ltd.

He, H., \& Mukherjee, A. (2007). I am, ergo I shop: Does store image congruity explain shopping behaviour of Chinese consumers? Journal of Marketing Management, 23(5-6), 443-460. https://doi.org/10. 1362/026725707X212766

Healton, C. G., Cummings, K. M., O’Connor, R. J., \& Novotny, T. E. (2011). Butt really? The environmental impact of cigarettes. Tobacco Control, 20(Suppl 1), i1-i1. https://doi.org/10.1136/tc.2011.043729

Heinen, E. (2016). Identity and travel behaviour: A cross-sectional study on commute mode choice and intention to change. Transportation Research Part F: Traffic Psychology and Behaviour, 43, 238-253.

Highman, A. (1955). The audited self-administered questionnaire. Journal of Marketing, 20(2), 155-159. https://doi.org/10.1177/002224295502000205

Hinton, D.E., Pham, T., Tran, M., Safren, S.A., Otto, M.W., \& Pollack, M.H. (2004). CBT for Vietnamese refugees with treatment-resistant PTSD and panic attacks: A pilot study. Journal of Traumatic Stress, 17(5), 429-433. https://doi.org/10.1023/B:JOTS.0000048956.03529.fa

Ho, R. (2006). Handbook of univariate and multivariate data analysis and interpretation with SPSS. CRC Press.

Hong, J. W., \& Zinkhan, G. M. (1995). Self-concept and advertising effectiveness: The influence of congruency, conspicuousness, and response mode. Psychology and Marketing, 12(1), 53-77. https://doi.org/ $10.1002 /$ mar.4220120105

Hosany, S., \& Martin, D. (2012). Self-image congruence in consumer behaviour. Journal of Business Research, 65(5), 685-691. https://doi.org/10.1016/j.jbusres.2011.03.015

Huber, F., Eisele, A., \& Meyer, F. (2018). The role of actual, ideal, and ought self-congruence in the consumption of hedonic versus utilitarian brands. Psychology and Marketing, 35(1), 47-63. https://doi. org/10.1002/mar.21070

Irfan, M., Hao, Y., Ikram, M., Wu, H., Akram, R., \& Rauf, A. (2021). Assessment of the public acceptance and utilization of renewable energy in Pakistan. Sustainable Production and Consumption, 27, $312-324$.

Johnston, A. C., \& Warkentin, M. (2010). Fear appeals and information security behaviours: an empirical study. MIS Quarterly, 549-566.

Joliffe, IT, \& Morgan, B. (1992). Principal component analysis and exploratory factor analysis. Statistical Methods in Medical Research, 1(1), 69-95. https://doi.org/10.1177/096228029200100105

Kaiser, H. F. \& Rice, J. (1974). Little Jiffy, Mark IV. Educational and Psychological Measurement, 34, 111-117.

Kaufmann, H. R., Petrovici, D. A., Filho, C. G., \& Ayres, A. (2016). Identifying moderators of brand attachment for driving customer purchase intention of original vs counterfeits of luxury brands. Journal of Business Research, 69(12), 5735-5747. https://doi.org/10.1016/j.jbusres.2016.05.003

Keizer, K., Lindenberg, S., \& Steg, L. (2008). The spreading of disorder. Science, 322, 1681-1685. https:// doi.org/10.1126/science.1161405

King, N., Burgess, M., \& Harris, M. (2019). Electric vehicle drivers use better strategies to counter stereotype threat linked to pro-technology than to pro-environmental identities. Transportation Research Part f: Traffic Psychology and Behaviour, 60, 440-452.

Kim, J., \& Muller, C. W. (1978). Introduction to factor analysis: What it is and how to do it. Beverly Hills: Sage Publishers.

Knox, A. (2005). An overview of incineration and EFW technology as applied to the management of municipal solid waste (MSW). ONEIA Energy Subcommitte, University of Western Ontario. Available 
online: http://www.durhamenvironmentwatch.org/Incinerator\%20Files\%20II/ OverviewOfIncinerationAndEFWKnox.pdf (Retrieved on 10 January 2020).

Kollmuss, A., \& Agyeman, J. (2002). Mind the gap: Why do people act environmentally and what are the barriers to pro-environmental behaviour? Environmental Education Research, 8(3), 239-260. https:// doi.org/10.1080/13504620220145401

Kressmann, F., Sirgy, M. J., Herrmann, A., Huber, F., Huber, S., \& Lee, D. J. (2006). Direct and indirect effects of self-image congruence on brand loyalty. Journal of Business Research, 59(9), 955-964. https://doi.org/10.1016/j.jbusres.2006.06.001

Krishna, R., \& Swamy, A. J. I. (2016). Chemical Flexi not-so-fantastic: A review on how the versatile material harms the environment and human health. Engineering, 2, 36-45.

Lamb, W. (2001). Keep America Beautiful: Grass roots non-profit or tobacco front group. PR Watch, 8(3).

Landon, E. L., Jr. (1974). Self concept, ideal self concept, and consumer purchase intentions. Journal of Consumer Research, 1(2), 44-51. https://doi.org/10.1086/208590

Laroche, M., Toffoli, R., Zhang, Q., \& Pons, F. (2001). A cross-cultural study of the persuasive effect of fear appeal messages in cigarette advertising: China and Canada. International Journal of Advertising, 20(3), 297-317. https://doi.org/10.1080/02650487.2001.11104895

LaTour, M. S., \& Pitts, R. E. (1989). Using fear appeals in advertising for AIDS prevention in the collegeage population. Journal of Health Care Marketing, 9(3).

Lee, J., Taneja, V., \& Vassallo, R. (2012). Cigarette smoking and inflammation: Cellular and molecular mechanisms. Journal of Dental Research, 91(2), 142-149. https://doi.org/10.1177/0022034511 421200

Lehman, P. K., \& Geller, E. S. (2004). Behaviour analysis and environmental protection: Accomplishments and potential for more. Behaviour and Social Issues, 13(1), 13-33.

Leistikow, B. N., Martin, D. C., \& Milano, C. E. (2000). Fire injuries, disasters, and costs from cigarettes and cigarette lights: A global overview. Preventive Medicine, 31(2), 91-99. https://doi.org/10.1006/ pmed.2000.0680

Li, F., Harmer, P., Duncan, T. E., Duncan, S. C., Acock, A., \& Boles, S. (1998). Approaches to testing interaction effects using structural equation modeling methodology. Multivariate Behavioral Research, 33(1), 1-39.

$\mathrm{Li}, \mathrm{X}$. (2009). An examination of effects of self-concept, destination personality, and SC-DP congruence on tourist behaviour (Doctoral dissertation, Virginia Tech). Retrieved from: https://theses.lib.vt.edu/ theses/available/etd 1010200918020 7/ unrestricted/Li_XP_D_2009.pdf

Lii, P., \& Kuo, F.-I (2016). Innovation-oriented supply chain integration for combined competitiveness and firm performance. International Journal of Production Economics, 174, 142-155. https://doi.org/10. 1016/j.ijpe.2016.01.018

Maciel, L. A. R., Loiola, R. L., \& Holanda, J. N. F. (2020). Feasibility of using cigarette butts waste in eco-friendly ceramic roofing tile. SN Applied Sciences, 2(12), 2014. https://doi.org/10.1007/ s42452-020-03672-4

MacInnis, D. J., \& Chun, H. E. (2007). Understanding hope and its implications for consumer behaviour: I hope, therefore I consume. Foundations and Trends® in Marketing, 1(2), 97-189.

Malhotra, M. K., \& Grover, V. (1998). An assessment of survey research in POM: From constructs to theory. Journal of Operational Management., 16, 407-425.

Malhotra, N. K. (1988). Self concept and product choice: An integrated perspective. Journal of Economic Psychology, 9(1), 1-28. https://doi.org/10.1016/0167-4870(88)90029-3

Mandliya, A., Varyani, V., Hassan, Y., Akhouri, A., \& Pandey, J. (2020). What influences intention to purchase sustainable products? Impact of advertising and materialism. International Journal of Productivity and Performance Management, 69(8), 1647-1669.

Markus, H., Ruvolo, A. (1989) Possible selves: Personalised representations of goals.

Markus, H., \& Nurius, P. (1986). Possible selves. American Psychologist, 41(9), 954.

Markus, H., \& Wurf, E. (1987). The dynamic self-concept: A social psychological perspective. Annual Review of Psychology, 38(1), 299-337.

Mathiyazhagan, K., Sengupta, S., \& Poovazhagan, L. (2018). A decision making trial and evaluation laboratory approach to analyse the challenges to environmentally sustainable manufacturing in Indian automobile industry. Sustainable Production and Consumption, 16, 58-67.

McKenzie-Mohr, D. (2011). Fostering sustainable behaviour: An introduction to community-based social marketing. New society publishers.

Mead, E. L., Rimal, R. N., Ferrence, R., \& Cohen, J. E. (2014). Understanding the sources of normative influence on behaviour: The example of tobacco. Social Science and Medicine, 115, 139-143. https://doi.org/10.1016/j.socscimed.2014.05.030 
Memish, K. E., Schüz, N., Frandsen, M., Ferguson, S. G., \& Schüz, B. (2017). Using self-affirmation to increase the effects of emotive health warnings on smoking: A randomised exploratory trial. Nicotine and Tobacco Research, 19(10), 1238-1242. https://doi.org/10.1093/ntr/ntw167

Mohajerani, A., Hui, S. Q., Shen, C., Suntovski, J., Rodwell, G., Kurmus, H., Hana, M., \& Rahman, M. T. (2020). Implementation of recycling cigarette butts in lightweight bricks and a proposal for ending the littering of cigarette butts in our cities. Materials, 13(18), 4023.

Mollema, E. D., Snoek, F. J., Pouwer, F., Heine, R. J., \& Van Der Ploeg, H. M. (2000). Diabetes fear of injecting and self-testing questionnaire: A psychometric evaluation. Diabetes Care, 23(6), 765769. https://doi.org/10.2337/diacare.23.6.765

Montano, D. E., \& Kasprzyk, D. (2015). Theory of reasoned action, theory of planned behaviour, and the integrated behavioural model. Health Behaviour: Theory, Research and Practice, 70(4), 231. https://doi.org/10.5771/9783845260341

Morgan, A. J. (1993). The evolving self in consumer behaviour: Exploring possible selves. ACR North American Advances.

Morgan, R. M., \& Hunt, S. D. (1994). The commitment-trust theory of relationship marketing. Journal of Marketing, 58(3), 20. https://doi.org/10.2307/1252308

Murugan, K., Suresh, U., Panneerselvam, C., Rajaganesh, R., Roni, M., Aziz, A. T., Hwang, J. S., Sathishkumar, K., Rajasekar, A., Kumar, S., Alarfaj, A. A., Higuchi, A., \& Benelli, G. (2018). Managing wastes as green resources: Cigarette butt-synthesised pesticides are highly toxic to malaria vectors with little impact on predatory copepods. Environmental Science and Pollution Research, 25, 10456-10470. https://doi.org/10.1007/s11356-017-0074-3

Novotny, T. E., Hardin, S. N., Hovda, L. R., Novotny, D. J., McLean, M. K., \& Khan, S. (2011). Tobacco and cigarette butt consumption in humans and animals. Tobacco Control, 20(Suppl 1), i17-i20. https://doi.org/10.1136/tc.2011.043489

Novotny, T., Lum, K., Smith, E., Wang, V., \& Barnes, R. (2009). Cigarettes butts and the case for an environmental policy on hazardous cigarette waste. International Journal of Environmental Research and Public Health, 6(5), 1691-1705.

Nunnally, J. C. (1994). Psychometric theory 3E. Tata McGraw-Hill Education.

Ogilvie, D. M. (1987). The undesired self: A neglected variable in personality research. Journal of Personality and Social Psychology, 52(2), 379. https://doi.org/10.1037/0022-3514.52.2.379

O'Leary-Kelly, S. W., \& Vokurka, R. J. (1998). The empirical assessment of construct validity. Journal of Operational Management, 16, 387-405.

Oliva, M., De Marchi, L., Cuccaro, A., \& Pretti, C. (2021). Bioassay-based ecotoxicological investigation on marine and freshwater impact of cigarette butt littering. Environmental Pollution, 288, 117787.

Pallant, J. (2007). SPSS survival manual: A step by step guide to data analysis using SPSS for windows. (3rd edn.). Open University Press.

Pennington, G. L., \& Roese, N. J. (2002). Regulatory focus and mental simulation. In Motivated social perception: The Ontario Symposium 9:277-298.

Podsakoff, P. M., \& Organ, D. W. (1986). Self-reports in organizational research: Problems and prospects. Journal of Management, 12(4), 531-544. https://doi.org/10.1177/014920638601200408

Podsakoff, P. M., MacKenzie, S. B., Bachrach, D. G., \& Podsakoff, N. P. (2005). The influence of management journals in the 1980s and 1990s. Strategic Management Journal, 26(5), 473-488. https://doi. org/10.1002/smj.454

Podsakoff, P. M., MacKenzie, S. B., Lee, J. Y., \& Podsakoff, N. P. (2003). Common method biases in behavioral research: A critical review of the literature and recommended remedies. Journal of Applied Psychology, 88(5), 879-903. https://doi.org/10.1037/0021-9010.88.5.879

Polegato, R., \& Bjerke, R. (2006). The link between cross-cultural value associations and liking: The case of Benetton and its advertising. Journal of Advertising Research, 46(3), 263-273. https://doi. org/10.2501/S0021849906060351

Puls, J., Wilson, S. A., \& Hölter, D. (2011). Degradation of cellulose acetate-based materials: A review. Journal of Polymers and the Environment, 19(1), 152-165.

Quan, S., \& Wang, N. (2004). Towards a structural model of the tourist experience: An illustration from food experiences in tourism. Tourism Management, 25(3), 297-305. https://doi.org/10.1016/ S0261-5177(03)00130-4

Rahman, M. T., Mohajerani, A., \& Giustozzi, F. (2020). Possible recycling of cigarette butts as fiber modifier in bitumen for asphalt concrete. Materials, 13(3), 734.

Rajesh, R., \& Rajendran, C. (2020). Relating environmental, social, and governance scores and sustainability performances of firms: An empirical analysis. Bus Strat Env., 29, 1247-1267. https://doi. org/10.1002/bse.2429 
Rajesh, R. (2018). On sustainability, resilience, and the sustainable-resilient supply networks. Sustainable Production and Consumption, 15, 74-88.

Rajesh, R. (2020). Exploring the sustainability performances of firms using environmental, social, and governance scores. Journal of Cleaner Production, 247, 119600.

Rasool, S., Rehman, A., Cerchione, R., \& Centobelli, P. (2021). Evaluating consumer environmental behavior for sustainable development: A confirmatory factor analysis. Sustainable Development, 29(2), 318-326.

Rath, J. M., Rubenstein, R. A., Curry, L. E., Shank, S. E., \& Cartwright, J. C. (2012). Cigarette litter: Smokers' attitudes and behaviours. International Journal of Environmental Research and Public Health, 9(6), 2189-2203. https://doi.org/10.3390/ijerph9062189

Rogers, R. W. (1975). A protection motivation theory of fear appeals and attitude change1. The Journal of Psychology, 91(1), 93-114. https://doi.org/10.1080/00223980.1975.9915803

Schultz, P. W., Bator, R. J., Large, L. B., Bruni, C. M., \& Tabanico, J. J. (2013). Littering in context: Personal and environmental predictors of littering behaviour. Environment and Behaviour, 45(1), 35-59. https://doi.org/10.1177/0013916511412179

Sengupta, M., Das, J., \& Maji, P. K. (2010). Environmental awareness and environment related behaviour of twelfth grade students in Kolkata: Effects of stream and gender. Anwesa, 5(1), 1-8.

Sherman, R. A., Nave, C. S., \& Funder, D. C. (2012). Properties of persons and situations related to overall and distinctive personality-behaviour congruence. Journal of Research in Personality, 46(1), 87-101. https://doi.org/10.1016/j.jrp.2011.12.006

Sirgy, M. J., \& Samli, A. C. (1985). A path analytic model of store loyalty involving self-concept, store image, geographic loyalty, and socioeconomic status. Journal of the Academy of Marketing Science, 13(3), 265-291.

Sirgy, M. J., Johar, J. S., Samli, A. C., \& Claiborne, C. B. (1991). Self-congruity versus functional congruity: Predictors of consumer behaviour. Journal of the Academy of Marketing Science, 19(4), 363-375. https://doi.org/10.1177/009207039101900409

Sirgy, M. J., Rahtz, D. R., Cicic, M., \& Underwood, R. (2000). A method for assessing residents' satisfaction with community-based services: A quality-of-life perspective. Social Indicators Research, 49(3), 279-316.

Slaughter, M. S., Pagani, F. D., Rogers, J. G., Miller, L. W., Sun, B., Russell, S. D., \& Adamson, R. M. (2010). Clinical management of continuous-flow left ventricular assist devices in advanced heart failure. The Journal of Heart and Lung Transplantation, 29(4), S1-S39. https://doi.org/10.1016/j.healun. 2010.01.011

Smith, E. A., \& McDaniel, P. A. (2011). Covering their butts: Responses to the cigarette litter problem. Tobacco Control, 20(2), 100-106. https://doi.org/10.1136/tc.2010.036491

Smith, E. A., \& Novotny, T. E. (2011). Whose butt is it? Tobacco industry research about smokers and cigarette butt waste. Tobacco Control, 20(Suppl 1), i2-i9. https://doi.org/10.1136/tc.2010.040105

Sobh, R., Juric, B., \& Lee, C. (2013). Self-regulation and consumer goal-directed behaviour: the role of the feared self in motivating behaviour and moderating persuasion. ANZMAC 2013 conference proceedings Adelaide 1-3 December 2003.

Solberg, Y., Rosner, M., \& Belkin, M. (1998). The association between cigarette smoking and ocular diseases. Survey of Ophthalmology, 42(6), 535-547. https://doi.org/10.1016/S0039-6257(98)00002-2

Son, J. (2018). Back translation as a documentation tool. Translation \& Interpreting, 10(2), 89.

Stefan, A. (2012). Fear appeals in social marketing. Retrieved from: http://pure.au.dk/portal-asb-student/ files/45284203/Anca_Stefan_BA_thesis_final_version.pdf

Stewart, D. W. (1981). The application and misapplication of factor analysis in marketing research. Journal of Marketing Research, 18, 51-62. https://doi.org/10.1177/002224378101800105.

Tabachnick, B., \& Fidell, L. S. (2007). Using multivarite statistics (5th edn.). Pearson Education, Inc. / Allyn and Bacon.

Tamim, H., Terro, A., Kassem, H., Ghazi, A., Khamis, T. A., Hay, M. M. A., \& Musharrafieh, U. (2003). Tobacco use by university students, Lebanon, 2001. Addiction, 98(7), 933-939. https://doi.org/10. 1046/j.1360-0443.2003.00413.x

Tannenbaum, M. B., Hepler, J., Zimmerman, R. S., Saul, L., Jacobs, S., Wilson, K., \& Albarracín, D. (2015). Appealing to fear: A meta-analysis of fear appeal effectiveness and theories. Psychological Bulletin, 141(6), 1178. https://doi.org/10.1037/a0039729

US Department of Health and Human Services (1981). https://www.cdc.gov/nchs/data/hus/hus81acc.pdf (Retrieved ond 14 Mar, 2017).

Valiente, R., Escobar, F., Pearce, J., Bilal, U., Franco, M., \& Sureda, X. (2020). Estimating and mapping cigarette butt littering in urban environments: A GIS approach. Environmental Research, 183, 109142. 
Vergara-Lopez, C., \& Roberts, J. E. (2012). Self-discrepancies among individuals with a history of depression: The role of feared self-guides. Cognitive Therapy and Research, 36(6), 847-853. https://doi.org/ 10.1007/s10608-011-9433-4

Werts, C. E., Linn, R. L., \& Jöreskog, K. G. (1974). Intraclass reliability estimates: Testing structural assumptions. Educational and Psychological Measurement, 34(1), 25-33. https://doi.org/10.1177/ 001316447403400104

WHO (2018). WHO global report on trends in prevalence of tobacco smoking 2000-2025; The World Health Organization: Geneva, Switzerland, 2018.

Williams, K. C. (2012). Fear appeal theory. Research in Business and Economics Journal, 5(1), 1-21.

Witte, K. (1992). Putting the fear back into fear appeals: The extended parallel process model. Communications Monographs, 59(4), 329-349. https://doi.org/10.1080/03637759209376276

Wolf, A., \& Seebauer, S. (2014). Technology adoption of electric bicycles: A survey among early adopters. Transportation Research Part a: Policy and Practice, 69, 196-211.

Woo, J. H., \& Au, E. K. (2008). Don't lose sight of age-related macular degeneration: The need for increased awareness in Singapore. Singapore Medical Journal, 49(11), 850.

World Health Organization. (1995). Environmental Issues. http://www.who.int/tobacco/Research/econo mics/rationale/ environment/en/ (Retrieved on 13 November 2016)

Xu, L., Shen, J., Marinova, D., Guo, X., Sun, F., \& Zhu, F. (2013). Changes of public environmental awareness in response to the Taihu blue-green algae bloom incident in China. Environment, Development and Sustainability, 15(5), 1281-1302. https://doi.org/10.1007/s10668-013-9440-6

Yarimoglu, E., \& Binboga, G. (2019). Understanding sustainable consumption in an emerging country: The antecedents and consequences of the ecologically conscious consumer behaviour model. Business Strategy and the Environment, 28, 642-651. https://doi.org/10.1002/bse.2270

Zafeiridou, M., Hopkinson, N. S., \& Voulvoulis, N. (2018). Cigarette smoking: An assessment of tobacco's global environmental footprint across its entire supply chain. Environmental Science and Technology, 52, 8087-8094.

Zhu, X., Teng, L., Foti, L., \& Yuan, Y. (2019). Using self-congruence theory to explain the interaction efects of brand type and celebrity type on consumer attitude formation. Journal of Business Research, 103, 301-309.

Ziadat, A. H. (2010). Major factors contributing to environmental awareness among people in a third world country/Jordan. Environment, Development and Sustainability, 12(1), 135-145.

Zogaj, A., Tscheulin, D. K., Lindenmeier, J., \& Olk, S. (2021). Linking actual self-congruence, ideal selfcongruence, and functional congruence to donor loyalty: The moderating role of issue involvement. Journal of Business Economics, 91(3), 379-400. https://doi.org/10.1007/s11573-020-01006-9

$\mathrm{Zu}, \mathrm{X}$., Robbins, T. L., \& Fredendall, L. D. (2010). Mapping the critical links between organizational culture and TQM/Six Sigma practices. International Journal of Production Economics, 123(1), 86-106. https://doi.org/10.1016/j.ijpe.2009.07.009

Publisher's Note Springer Nature remains neutral with regard to jurisdictional claims in published maps and institutional affiliations. 